Boise State University

ScholarWorks

Marketing and Finance Faculty Publications and

Presentations

Department of Marketing and Finance

7-15-2008

Drucker's Insights on Market Orientation and Innovation: Implications for Emerging Areas in High-Technology Marketing

Shikhar Sarin

Boise State University

Jakki J. Mohr

University of Montana 
This is an author-produced, peer-reviewed version of this article. The final, definitive version of this document can be found online at Journal of the Academy of Marketing Science (doi: 10.1007/s11747-008-0101-5) published by Springer. Copyright restrictions may apply.

\title{
Drucker's Insights on Market Orientation and Innovation: Implications for Emerging Areas in High-Technology Marketing
}

\author{
Jakki J. Mohr \\ Jeff and Martha Hamilton Distinguished Faculty Fellow \\ Professor of Marketing \\ School of Business Administration, University of Montana \\ Shikhar Sarin \\ Professor of Marketing \\ College of Business and Economics, Boise State University
}

The authors are grateful to three anonymous reviewers for their helpful comments and constructive feedback.

\begin{abstract}
In 1954, Drucker boldly declared that organizations have only two basic functions, marketing and innovation. While true for any organization, this insight is particularly pertinent for technology-based businesses. The complicated environment surrounding high-tech companies creates a great need for sophisticated marketing, yet these companies continue to have under-developed competencies in marketing and in understanding customer needs. In its first two sections, this essay explores Drucker's insights with respect to two particularly salient issues for high-tech companies: developing and implementing a market orientation, and sustained break-through innovations. We review Drucker's insights and synthesize them with the scholarly research on these issues. In the third section, we discuss three emerging areas in hightech marketing where academics and managers could build on Drucker's insight to guide future research and practice: market-driving, customer co-creation, and corporate social responsibility. The illustrative examples provided by these emerging areas highlight that even today, Drucker's writings continue to offer remarkable guidance to scholars and managers who are willing to take the time to reflect, understand, and incorporate these insights in the unique context of high-tech industries.
\end{abstract}

"There is only one valid definition of business purpose: to create a customer. .... Therefore, any business enterprise has two-and only two-basic functions: marketing and innovation."

-- Peter Drucker (1954), The Practice of Management, pp. 39-40

Although this quote captures the challenge any company or organization faces, it is particularly apt for technology-based companies. Marketing managers in technology-based companies face many complications that make their job more complex and challenging than in more traditional companies. For example, complications arise from: "balky" consumers who sometimes prefer to stall their purchase decision of technology-related products until it is perceived to be less risky (Dhebar 1996); the "chasm" that makes the diffusion process slow at best and fraught with uncertainty (Goldenberg, Labai, and Muller 2002; Moore 1991); high rates of obsolescence, and high levels of technological and market uncertainties (Mohr, Sengupta, and Slater 2005).

The combination of these and other complicating factors create an extremely difficult situation not unlike double jeopardy: the complex environment of high-tech marketing implies a need for sophisticated marketing prowess; however, all too often, these very companies either lack the needed marketing talent and expertise, or fail to provide adequate support and resources the marketing personnel need to be effective (Dutta, Narasimhan, and Rajiv 1999).

Despite the fact that superior technology is the raison $d$ ' etre for the high-tech industry, the second basic organizational function highlighted by Drucker, innovation, remains a challenge for most technologybased companies. Established high-tech companies struggle to maintain a sustained and successful stream of non-incremental innovations. Due to inertia, organizations often find that the superior technology that formed the basis for their initial success eventually become a liability. Rather than developing new and innovative technology platforms, established hightechnology companies often strive to protect their initial innovations without aggressively pursuing newer innovations (Christensen 1997; Leonard-Barton 1992). Moreover, technology firms constantly face a challenge in ensuring that their technological innovations are not merely a bundle of cutting-edge features and gadgets, but rather are designed in the service of customer needs (cf., Thompson, Hamilton and Rust 2005). 
This is an author-produced, peer-reviewed version of this article. The final, definitive version of this document can be found online at Journal of the Academy of Marketing Science (doi: 10.1007/s11747-008-0101-5) published by Springer. Copyright restrictions may apply.

Drucker's famous quote hones the focus for marketing and innovation efforts on creating customers. Yet, interactions of technology-based companies with their customers remain complex and/or unfocused. Customers of new technologies often find it difficult to articulate their needs and understand the specific benefits new technologies can offer (Leonard-Barton and Rayport 1997; Leonard-Barton, Wilson, and Doyle 1995). As a result, technology-based companies often find it difficult to develop a competency in working with customers-both on the fuzzy front-end of product development when it is vitally important to solicit customer input (cf. Reid and Brentani 2004), as well as on the back-end in providing after-sales service and support. In addition, high-tech companies often diffuse their marketing efforts related to new technologies across too many segments to have a meaningful impact (Moore 1991).

In light of these challenges, the purpose of this essay is to explore Drucker's insights with respect to two particularly salient issues for high-technology companies: the need for a customer- or marketorientation, and the need for sustained innovativeness in the service of customer needs. In particular, the first two sections of this essay explore Drucker's writings in these two inter-related areas, and tie them to the extant body of literature on marketing of high-tech products and innovations. It is truly remarkable that when taken in the context of high-tech marketing - a field that really did not find academic legitimacy till the 1990s (cf. John, Weiss and Dutta 1999)—concepts such as a market orientation, market driving, and disruptive innovation, were raised or addressed by Drucker in his writings long before they appeared in the academic literature. Integrating the research on technology-based marketing with Drucker's earlier writings demonstrates his prescience nearly half-a-century ago regarding technology and innovation marketing.

In addition to a retrospective tie of Drucker's writings to more current academic research, we also explore Drucker's writings for forward-looking guidance for academics and managers engaged in the marketing of high-tech products and innovations. In this spirit of building on Drucker's insights, the third section of this essay presents illustrative examples of three emerging areas in high-tech markets: market-driving, customer co-creation, and corporate social responsibility--and explores way to build on Drucker's insights in future research and practice. We conclude this essay by demonstrating that, even today, Drucker's writings continue to offer remarkable guidance to scholars and managers who are willing to take the time to reflect, understand, and incorporate his insights in the unique context of high-tech industries.

\section{Drucker's Insights on Market-Orientation and Implications for High-Tech Marketing}

This section delves into Drucker's writings with a focus on its ties to the development of the concept of market orientation in the marketing literature. In particular, we highlight the conceptualization of the construct and the impact of market orientation on firm performance. In addition, we note the boundary conditions of the research on the market orientation-performance relationship, highlighting findings specific to high-tech markets. A key focus of research (and Drucker's writings) in this regard is the need for inter-functional coordination; because of the importance of this topic to high-tech companies, we pay specific attention to this area. Finally, we conclude this section with discussion of the potential drawbacks of a reactive market orientation and the benefits of a proactive market orientation or market driving, particularly in high-tech markets.

\section{Market Orientation: The Construct and Its Outcomes}

Selling and marketing are antithetical rather than synonymous or even complementary. There will always be, one can assume, a need for some selling. But the aim of marketing is to make selling superfluous. The aim of marketing is to know and understand the customer so well that the product or service fits her and sells itself. Ideally, marketing should result in a customer who is ready to buy.... (Drucker 1973, Management: Tasks, Responsibilities, Practices, pp. 64-65).

Drucker was amongst the first to propose the notion that marketing is not just selling but, rather, understanding the customer. Consistent with his arguments, most introductory marketing textbooks today teach how the dominant paradigm in marketing evolved from a "selling concept" focused on promotional efforts designed to overcome customer resistance, to a "marketing concept" focused on determining the needs and wants of the customers and delivering satisfaction along those lines. Such market-driven organizations display a mastery of market-sensing and customerlinking capabilities (Day 1994).

... business [must] start out with the needs, the realities, the values of the customer. It [consumerism] demands that business define its goal as the satisfaction of customer needs. It demands that business base its rewards on the contribution to the customer 
This is an author-produced, peer-reviewed version of this article. The final, definitive version of this document can be found online at Journal of the Academy of Marketing Science (doi: 10.1007/s11747-008-0101-5) published by Springer. Copyright restrictions may apply.

(Drucker 1973, Management: Tasks, Responsibilities, Practices, pp. 64-65).

Without labeling it as such, over the decades Drucker articulated the philosophical underpinnings of what later came to be regarded as "market orientation." Drucker's insights closely mirrored later developments in the marketing discipline with respect to how the concept of market orientation was first articulated, and how it continues to evolve. Consistent with Drucker's writings, distinct but complementary views of market orientation (MO) emerged in the literature (Hult, Ketchen and Slater 2005): ${ }^{1}$

- $\quad \mathrm{MO}$ as a corporate culture that puts customers' interests first (e.g., Deshpande, Farley and Webster 1993)

- $\mathrm{MO}$ as a combination of customer orientation and competitor orientation (and interfunctional coordination) (e.g., Day and Wensley 1988; Narver and Slater 1990)

- $\mathrm{MO}$ as the generation and dissemination of, and responsiveness to, market intelligence/information (e.g., Kohli and Jaworski 1990; Jaworski and Kohli 1993).

An extensive literature has established a positive link between market orientation and firm performance (see Ellis 2006 for a review and meta-analysis of 56 empirical studies). In addition to its relationship with firm performance, $\mathrm{MO}$ has been shown to be positively related to product innovation (Han, Kim, and Srivastava 1998; Lukas and Ferrell 2000), new product performance (Kyriakopoulos and Moorman 2004), and product/market exploitation and exploration (AtuaheneGima 2005; Kyriakopoulos and Moorman 2004).

\section{Boundary Condition: The Role of Market Orientation} in High-Tech Companies. Earlier research suggested that the relationship between market orientation and firm performance was robust regardless of environmental conditions like market turbulence, technological turbulence, competitive intensity, and market growth rates (Jaworski and Kohli 1993; Slater and Narver 1994). Slater and Narver (1994) further argued that being market-oriented was cost effective in the long-term regardless of a firm's environmental conditions. Although more recent studies indicate that the market orientation/firm performance relationship is

${ }^{1}$ Due to space constraints, the supporting Table linking Drucker's works to contemporary research in marketing is not included. Please contact the first author for a copy of this Table. much stronger in highly dynamic markets (Homburg and Pflesser 2000), which are characteristic of technology-oriented industries. However Drucker notes:

"Despite the emphasis on marketing and the marketing approach, marketing is still rhetoric rather than reality in far too many businesses" (Drucker 1973, Management: Tasks, Responsibilities, Practices, pp. 64-65).

This is particularly true for high-tech firms, where the engineering brilliance that created the new innovation in the first place takes on a higher status in the organization relative to the needed marketing skills (Leonard-Barton 1992). Leonard-Barton further notes that either implicitly or explicitly, the preference for engineering-related knowledge and skills becomes a type of core rigidity - a barrier to the cultivation of marketing talents and expertise.

Similarly, Drucker suggested that the need for market information is particularly important for knowledgebased innovations, like the ones seen in most high-tech industries, compared to other types of innovations:

"It may seem paradoxical, but knowledgebased innovation is more market-dependent than any other kind of innovation. Careful analysis of the needs-and above all, the capabilities-of the intended user is essential" (Drucker 1985a, p. 9).

Hence, for technology-based companies, the need to be market- or customer-oriented is particularly important.

Dutta, Narasimhan, and Rajiv (1999) found a strong interaction between the technological and marketing capabilities of a firm, where firms with a strong $R \& D$ and technological base stood to gain the most from a strong marketing capability. They further argue that a strong market orientation is one of the most fertile sources of ideas for innovation. Firms in high-tech markets need to excel not only at generating new innovations that deliver value to customers, but also at commercializing these innovations. Not surprisingly, market orientation has been shown to lead to greater creativity and new product performance in high-tech firms (Im and Workman 2004). These findings indicate that superior technology alone is insufficient for achieving marketplace success for high-tech firms. Conversely, a strong market orientation without commensurate development of a strong innovation/technological capability can have a negative effect on new product and market performance (Baker and Sinkula 2005). 
This is an author-produced, peer-reviewed version of this article. The final, definitive version of this document can be found online at Journal of the Academy of Marketing Science (doi: 10.1007/s11747-008-0101-5) published by Springer. Copyright restrictions may apply.

Taken together, these arguments suggest that a combination of effective marketing and superior technology/innovation capability is needed for the highest levels of marketplace success in high-tech industries (Baker and Sinkula 2005; Dutta, Narasimhan, and Rajiv 1999). The brilliance of Drucker is evident in the fact that he reached the same conclusion five decades earlier when he boldly declared:

\begin{abstract}
"There is only one valid definition of business purpose: to create a customer. .... Therefore, any business enterprise has two-and only two-basic functions: marketing and innovation" (Drucker 1954, The Practice of Management, pp. 39-40).
\end{abstract}

Specific Implications for Cross-Functional Integration. Drucker's emphasis on marketing and innovation as the primary functions of a business was not intended to undermine the value, or contributions, of other functional areas. To the contrary, marketing has long been regarded as a boundary spanning activity (e.g., Goolsby 1992), and innovation has long been recognized as a cross-functional activity (Gupta, Raj, and Wilemon 1986; Sarin and Mahajan 2001). Drucker's assertion only serves to highlight the need to closely integrate marketing with other functional areas. For example, Gupta, Raj, and Wilemon (1986) contend that for greater innovation effectiveness, the need for marketing-R\&D integration increases with the level of innovation desired and the environmental uncertainty experienced. The lack of such integration, as evidenced by rivalry between the two functions, severely reduces the use of relevant marketing information by $R \& D$, which neglects useful information based on misperceptions about the quality of information supplied by marketing (Maltz, Souder, and Kumar 2001).

From an innovation and new product development perspective, integration between marketing and $R \& D$ has received bulk of the attention over the years (e.g., Fisher, Maltz, and Jaworski 1997; Gupta, Raj, and Wilemon 1986); however, researchers have also emphasized the need to integrate marketing with manufacturing (e.g., Ruekert and Walker 1987), logistics (e.g., Rinehart, Cooper, and Wagenheim 1989), and more recently, finance (e.g., Srivastava, Shervani, and Fahey 1998). Similarly, seminal research on market orientation acknowledges the critical role of crossfunctional integration (Narver and Slater 1990), and inter-departmental relations (Jaworski and Kohli 1993; Kohli and Jaworski 1990) in creating market-oriented organizations, and delivering superior customer value and organizational performance. Drucker's quote regarding marketing and innovation being the primary functions of a business also serves to remind that all functions need to be innovative and market-orientednot just marketing and product development/management.

Reactive versus Proactive (Market Driving) Market Orientation. It is worth noting that Drucker proposed creating a customer as the primary objective of business, not just serving the customer. This distinction is critical because the concept of market orientation has been criticized as being reactive and too narrowly focused on existing customers (Atuahene-Gima, Slater, and Olson 2005; Narver, Slater, and MacLachlan 2004). Narver, Slater, and MacLachlan (2004) note that overreliance on what customers' state as their new product needs can leave a business highly vulnerable. A "slavish" devotion to existing customers often stifles disruptive innovations and can lead companies to miss emerging opportunities in the market (Christensen 1997).

It is always with non-customers that basic changes begin and become significant. At least half of the important new technologies that have transformed an industry in the past fifty years came from outside the industry itself (Drucker 1999, Management Challenges for the $21^{\text {st }}$ Century, pp. 121-123).

Day (1994) contends that market-driven organizations are able not only to diagnose current needs of the market and their own capabilities, but also to anticipate future needs and capabilities. Recent evolution in the market orientation concept builds on this notion by proposing that market orientation is both responsive/reactive and proactive in nature (AtuaheneGima, Slater, and Olson 2005; Narver, Slater, and MacLachlan 2004). Responsive market orientation addresses the expressed needs of the customer, in line with the traditional notion of $\mathrm{MO}$; proactive market orientation addresses the latent needs of the customer and creates opportunities for providing value to the customer of which s/he is unaware (Narver, Slater, and MacLachlan 2004). While responsive market orientation is generally regarded as being marketdriven, proactive market orientation is more compatible with the emerging concept of market-driving - an approach which seeks to actively influence the structure of the market and/or the behavior of market players to enhance a firm's competitive position (Jaworski, Kohli and Sahay 2000). The latter is consistent with Drucker's notion of creating a customer. We will delve further into the issue of market driving in hightechnology environments in the third section of this essay, Building on Drucker's Insights: Implications for Three Emerging Areas. 
This is an author-produced, peer-reviewed version of this article. The final, definitive version of this document can be found online at Journal of the Academy of Marketing Science (doi: 10.1007/s11747-008-0101-5) published by Springer. Copyright restrictions may apply.

\section{Drucker's Insights on Innovation and Implications for High-Tech Marketing}

\begin{abstract}
"Core competencies are different for every organization; they are, so to speak, part of an organization's personality. But every organization-not just businesses-needs one core competence: innovation" (Drucker 1999, Management Challenges for the $21^{\text {st }}$ Century, p. 119).
\end{abstract}

Clearly, to remain successful, companies cannot rest on their past successes. They must continuously innovate in order to survive in the marketplace. In his 1985 Harvard Business Review article, Drucker specifically identified the notion of "knowledge-based innovations" as those that are based on either scientific or technical knowledge (i.e., radical technological innovations), and described their characteristics:

There is a protracted span between the emergence of the new knowledge and its distillation into usable technology. Then there is another long period before this new technology appears in the marketplace in products, processes, or services. ... During a long gestation period, there is a lot of talk and little action. Then, when all the elements suddenly converge, there is tremendous excitement and activity and an enormous amount of speculation (Drucker 1985a, pp. 89).

Yet, many companies, including technology-based companies, experience difficulties in consistently generating break-through innovations:

Market domination tends to lull the leader to sleep .... Market domination produces tremendous internal resistance against any innovation and thus makes adaptation to change dangerously difficult (Drucker 1973, Management: Tasks, Responsibilities, Practices, pp. 105-107).

This difficulty occurs for a variety of reasons, such as the "liability of bigness," the tendency to over-value prior investments in legacy technologies and product offerings, complacency/inertia, and blindness to market changes, among others (Chandy and Tellis 2000; Mohr, Sengupta, and Slater 2005). Even when high-tech companies offer a steady stream of cutting-edge innovations, they can struggle with the proper strategies to achieve market success. For example, is it better to be a pioneer, offering "bleeding edge" technologies, or to be a fast follower (cf. Slater, Hult, and Olson 2007)?
High-tech companies face many challenges and a bewildering array of strategies to be innovative. Indeed, Drucker's writings offered many insights for innovation; this section focuses specifically on several issues that are particularly vexing to high-tech companies: innovator's dilemma and various solutions to overcoming inertia in developing breakthrough innovations; how a company gathers market-based information to guide innovation efforts; and how a company measures its innovation performance.

\section{The Innovator's Dilemma}

Drucker specifically identifies a company's current successes as a potential rigidity in on-going innovation.

Innovation “makes obsolete yesterday's capital equipment and capital investment. The more an economy progresses, the more capital formation will it therefore need. Thus, what the classical economist-or the accountant or the stock exchange-considers 'profit' is a genuine cost, the cost of staying in business, the cost of a future in which nothing is predictable except that today's profitable business will become tomorrow's white elephant" (Drucker 1993, The Ecological Vision, pp. 111-112).

Today's scholars refer to this phenomenon as the “innovator's dilemma" (cf. Christensen 1997). This stream of research largely contends with the issue: why do established companies have difficulty both innovating and responding to disruptive innovations? The difficulty of established companies to introduce disruptive innovations is not simply due to failures in product development. It is also due to sunk costs that create a bias in managerial decision making, as well as an excessive reliance on a certain class of customers (e.g., Daneels 2002), where "focusing on their current customers, managers literally do not see other opportunities" (Henderson, 2006, p. 7). Hence, successful companies tend to be overly dedicated to their existing customer base and serving existing customers' needs (Atuahene-Gima, Slater, and Olson 2005; Narver, Slater, and MacLachlan 2004). In order to avoid falling into such a trap, companies need to constantly look beyond their existing customer base (Christensen and Raynor 2003).

A key aspect of the theory of disruption is that the mismatch between the ever-sophisticated feature set of product offerings and customers' capabilities to use that sophisticated feature set creates a gap in the marketplace; newer entrants can enter the market with lower-end products, first selling them to lower-end customers (i.e., least attractive to established companies), but eventually making inroads into the 
This is an author-produced, peer-reviewed version of this article. The final, definitive version of this document can be found online at Journal of the Academy of Marketing Science (doi: 10.1007/s11747-008-0101-5) published by Springer. Copyright restrictions may apply.

established company's customer base. Therefore, if a new innovation arises that serves different customers in different ways, established companies may tend to overlook or to minimize its potential impact on their businesses (Christensen 1997).

Solutions to the Innovator's Dilemma. Simply being aware of the sources of innovation inertia is insufficient to overcoming them. Drucker's writings are filled with insights about how to maintain a culture of innovativeness.

One key solution is "creative destruction" (Schumpeter 1942), ${ }^{2}$ or the willingness to pursue new sources of revenue via new products and new customers, even at the expense of a company's existing "cash cows."

Innovating organizations spend neither time nor resources on defending yesterday. Systematic abandonment of yesterday alone can free the resources, and especially the scarcest resource of them all, capable people, for work on the new. Your being the one who makes your product, process, or service obsolete is the only way to prevent your competitor from doing so (Drucker 1992, Managing for the Future, pp. 281-282).

More recently, Chandy and Tellis (1998) refer to this as "constructive cannibalism."

In addition to drawing from Schumpeter's notion of creative destruction, Drucker identified structural and knowledge-/information-based solutions (similar in spirit to the prior section on market orientation) as keys to overcoming innovation inertia. For example, with respect to structural solutions to overcoming resistance to innovation, Drucker argued in favor of creating a clear separation between those charged with developing new innovations and those managing existing business units (Drucker 1985a).

Another way to avoid the innovator's dilemma is to take a broad view of markets, customers, and sources of information. Drucker advocated defining one's business, not in terms of existing customers, products, or markets, but in terms of what needs (articulated or latent) are being satisfied. Drucker realized the value of casting a wide net for sources of information in the strategy formulation process when a company's technology/product road map is developed.

\footnotetext{
${ }^{2}$ Drucker's thoughts on innovation were influenced by Joseph Schumpeter (1942), whom he cited at length in The Ecological Vision (1993).
}

Strategy has to be based on information about markets, customers, and non-customers, about technology in one's own industry and others' ...Major changes always start outside an organization (Drucker 1999, Management Challenges for the $21^{\text {st }}$ Century, pp. 121-123).

Sources of Information for Innovation. Drucker's focus on broad-based information presents a key challenge to high-technology companies. Especially since, the ability of customers to provide meaningful input for radical innovation is often questionable. Customers may be completely unaware of what new technologies are available or how those technologies might be used to solve the problems they face. They find it very difficult to envision how new technology can meet their needs. As a result, customer input is likely to lead only to incremental improvements rather than break-through ideas (Leonard-Barton, Wilson, and Doyle 1995).

Because of these limitations, managers in high-tech industries have come to rely on novel methods of market research, such as lead users (von Hippel, Thomke, and Sonnack 1999) and empathic design (Leonard-Barton and Rayport 1997). Mohr, Sengupta, and Slater (2005) explicitly refer to the use of novel research techniques as a critical ingredient in successful high-technology marketing. In order for Drucker's insights to continue to be of value, high-tech companies must actively seek not only new sources of information, but also new methods of acquiring and analyzing information. Drucker noted that major changes always start outside an organization. As such, research tools, approaches and methodologies that bring forth new information not only are critical to the innovation process, but also are constitute essential building blocks of market-oriented organizations (cf. Kohli and Jaworski 1990).

Customer co-creation is emerging as one area where scholars could build on Drucker's insights, especially with respect to generating break-through innovation. Customer co-creation involves collaborative activities that actively engage customers in the design and development of new innovations; it brings an "outsidein" perspective to development, in contrast to the more traditional and internally-focused stage-gate process (O'Hern and Rindfleish 2006; Vargo and Lusch 2004). The third section of this essay discusses how academics and managers could build on Drucker's writings in emerging areas, such as customer co-creation, in hightech markets. 
This is an author-produced, peer-reviewed version of this article. The final, definitive version of this document can be found online at Journal of the Academy of Marketing Science (doi: 10.1007/s11747-008-0101-5) published by Springer. Copyright restrictions may apply.

\section{Innovation and Marketing Metrics}

We conclude this section on innovation with a final innovation topic that Drucker raised years ago: the link between innovation and financial performance:

\begin{abstract}
"Tomorrow's economics must answer the questions: 'How do we relate the way we run a business to results? What are results?' The traditional answer-'the bottom line'-is treacherous. Under a bottom-line philosophy, we cannot relate the short run to the long term, and yet the balance between the two is a crucial test of management. The beacons of productivity and innovation must be our guideposts. If we achieve profits at the cost of downgrading productivity or not innovating, they aren't profits. We're destroying capital. On the other hand, if we continue to improve productivity of all key resources and improve our innovative standing, we are going to be profitable. Not only today, but tomorrow" (Drucker 1993, The Ecological Vision, p. 99).
\end{abstract}

Drucker's emphasis on financial performance preceded the emergence of the issue of marketing metrics and financial accountability of marketing activities (e.g., how one links marketing investments and decisions to measurable outcomes) (Srivastava, Shervani, and Fahey 1998).

Specifically in innovation research, capturing the rewards of innovation is emerging as a major theme (Hauser, Tellis, and Griffin 2006). Since innovation can occur at several different levels in an organization, different metrics have traditionally been applied to the measurement of innovation, including measures of the innovation's appropriateness (i.e., usefulness) and novelty (Sethi, Smith and Park 2001), and the quality, level of innovativeness, adherence to budget and schedule, and speed to market (e.g., Sarin and Mahajan 2001). Probably the most common metric of innovation performance is its impact on the financial value of firm, and other similar outcome variables (cf. Tellis 2006). However, Drucker would likely find these metrics insufficient:

“... every organization needs a way to record and appraise its innovative performance. In organizations already doing that ... the starting point is not the company's own performance. It is a careful record of the innovations in the entire field during a given period. Which of them were truly successful? How many of them were ours? Is our performance commensurate with our objectives? With the direction of the market? With our market standing? With our research spending? Are our successful innovations in the areas of greatest growth and opportunity? How many of the truly important innovation opportunities did we miss? Why? Because we did not see them? Or because we saw them but dismissed them? Or because we botched them? And how well do we do in converting an innovation into a commercial product? ...it raises the right questions" (Drucker 1999, Management Challenges for the $21^{\text {st }}$ Century, p. 119).

Drucker's concerns in this respect serve to broaden the focus of measuring innovation performance beyond a company's own performance-the most commonly used measure in the literature today-by comparing the company's achieved/attained performance to that which was possible. The questions Drucker raised in the quote above encourage and guide inquiry on innovation measurement not only to account for the opportunity costs, but also to consider the "why" explanations for a company's attained performance. Future research can build on these ideas by operationalizing the metrics advocated by Drucker and examining the how well they correlate with those commonly used in the literature. It would also be interesting to explore whether Drucker's metrics potentially lead companies to a different conclusion regarding the success of their innovation efforts, compared to their existing metrics.

\section{Building on Drucker's Insights: Implications for Three Emerging Areas}

Despite Drucker's prescient insights about the importance of marketing and innovation, particularly as they apply to technology-based companies, it would be nearly impossible for anyone individual, even as great a management thinker as Drucker, to have anticipated all of the remarkable and exciting changes that are emerging in the early part of the $21^{\text {st }}$ century. ${ }^{3}$ In this section, we address just a few of these market changes and explore how academics and managers can build on Drucker's writings to guide theory development and managerial practice in three emerging areas in high-tech marketing: market-driving, customer co-creation, and corporate social responsibility. ${ }^{4}$

${ }^{3}$ To the best of our knowledge, based on a comprehensive rather than exhaustive review of Drucker's writings.

4 These three areas were chosen because Drucker's insights were influential in the evolution of these emerging areas; and because these areas are relevant to both market orientation and innovation, the two dominant themes explored in this essay. We acknowledge that Drucker's impact on theory and practice is much too great to be captured in 
This is an author-produced, peer-reviewed version of this article. The final, definitive version of this document can be found online at Journal of the Academy of Marketing Science (doi: 10.1007/s11747-008-0101-5) published by Springer. Copyright restrictions may apply.

In high-tech industries, market driving, customer cocreation, and corporate social responsibility would constitute significant innovations in business strategy. While he may not have articulated or addressed these issues specifically, Drucker understood the importance of innovation in strategy and business models:

Under the other entrepreneurial strategies, the innovator has to come up with an innovative product or service; here the strategy itself is the innovation. The innovative strategy converts an existing product or service into something new by changing its utility, its value, and its economic characteristics. There is new economic value and new customers, but no new product or service. ... This changes the characteristics of the industry (Drucker 1985a, Innovation and Entrepreneurship, pp. 43, 247).

\section{Market Driving}

Drucker's emphasis on "creating customers" is strongly linked to the notion of market driving, which has powerful ramifications for managerial decision making and marketing strategy, particularly when combined with the unique characteristics of high-tech markets (i.e., market/technological uncertainty, competitive volatility, short product life cycles, network externalities, etc.). Market driving seeks to actively influence the structure of the market and/or the behavior of market players to enhance a firm's competitive position (Jaworski, Kohli, and Sahay 2000). Hence, in addition to being focused on the customer, market driving activities are focused on many different stakeholders such as, competitors, vendors, potential partners and allies, and regulators (Hills and Sarin 2003).

In the context of high-tech markets, issues related to the size and growth of the installed base, the development of ecologies or networks of alliances/partnerships that push for the establishment of particular technological platforms as industry standards, and the availability of compatible and complementary products (Arthur 1996; Hill 1997; Schilling 2002) become critically important for driving markets. Referred to as network effects, these issues suggest that the value any one customer

just three examples, or even a few essays. Thus rather than attempting the near-impossible task of being comprehensive in documenting Drucker's impact, we offer these three areas as illustrative examples of how contemporary scholars and practitioners can extend Drucker's thinking in the contexts of high-tech markets. receives from a product is the function of: (a) the size of the installed base-or how many other customers also have bought and use the same product/technology; and (b) the number of complementary/compatible products available, and the number of firms supporting the technology through partnerships and alliances. ${ }^{5}$ In fact, because of these issues related to network effects, Hills and Sarin (2003) argue, theoretically, that marketdriving can be more predictive of long-term survival and success in high-tech markets than being marketdriven. Other researchers argue that a balance between being market-driven and market-driving may be necessary to ensure success (Atuahene-Gima, Slater, and Olson 2005; Narver, Slater, and MacLachlan 2004).

Future research that builds on Drucker's insights about "creating customers" could leverage this nascent research on market-driving. First and foremost, researchers in this area must come up with a reliable and valid measure for capturing the construct. Then, in the context of high-tech markets specifically, the research could usefully explore the boundary conditions for the market-driving phenomenon and its relationship to network effects:

- Under what circumstances are market-driven activities likely to be more successful than market driving activities?

- What is the optimal mix of emphases on different stakeholders in market driving? In other words, under what conditions should market-driving activities be directed at one stakeholder versus another?

- Is there a critical threshold in terms of the size or quality of the network (and/or user base) that needs to be crossed before the network (and by association, the technological standard it supports) is perceived to be stable and reliable?

An interesting by-product of the network environment surrounding many high-tech innovations is the creation of "winner take all" economies, where over time, one technological platform comes to dominate the market disproportionately relative to other alternatives (Arthur 1996; Hill 1997). This leads to the creation of de facto

\footnotetext{
${ }^{5}$ Increasing returns effects are seen in industries as wide ranging as the many popular social networking sites today, to any industry based on a particular technology platform where connectivity across users is desired (computer gaming, software compatibility, etc.). Interestingly, despite Drucker's many insights regarding the need to understand market forces, the topic of network effects does not appear to have received much attention in his writings.
} 
This is an author-produced, peer-reviewed version of this article. The final, definitive version of this document can be found online at Journal of the Academy of Marketing Science (doi: 10.1007/s11747-008-0101-5) published by Springer. Copyright restrictions may apply.

monopolies, such as the one attained by Microsoft in the PC operating system arena. The push for market dominance raises some interesting issues related to the strategy of pioneering versus following. While evidence indicates that in general long-term advantages of pioneering might be debatable (Tellis, Golder, and Christensen 2001), more recent research (Vardarajan, Yadav, and Shanker 2005) suggests that pioneering advantages in networked environments may be stronger. While Drucker did not elaborate much on network externalities, he seemed to believe in the connection between pioneering and market leadership:

"First with the most" ... describes the strategy in which an innovator looks to attain leadership, if not outright dominance. This is the entrepreneurial strategy with the potentially highest rewards; but it's also the most risky one. There can be no mistakes or second chances. The outcome is either market and industry leadership or nothing at all. Entrepreneurs must be right the first time; otherwise, they fail. For every innovator that succeeds with this strategy, dozens fail. Yet if the "first with the most" strategy succeeds, the innovator reaps tremendous rewards. It's the strategy that underlies the success and market leadership of such giants as $3 \mathrm{M}$, Procter \& Gamble, Intel, and Microsoft" (Drucker 1985a, Innovation and Entrepreneurship, pp. 210211).

From a marketing-driving perspective, it would be interesting to examine to what extent pioneering firms have a greater probability of establishing dominant standards in networked high-tech markets (e.g., Srinivasan, Rangaswamy and Lilien (2004). Similarly, the emergence of de facto monopolies as a by-product of network effects and market-driving raises interesting public policy issues.

- Should regulators intervene to protect consumer interests in conditions subject to network effects, or would that be unfairly punishing success in such markets? What criteria should be used to make such a determination?

Although Drucker alluded to the importance of multiple stakeholders and their effects on a business, he may not have fully appreciated the degree to which marketplace networks, partnerships, and alliances would become integrated into the company's business strategy. In high-tech industries in particular, managers must become adroit at navigating today's environment of virtual business teaming, fluid market partnerships, coopetition, and other such alliances. This need to establish extended business networks, and industry standards opens up several issues for further exploration:

- What kind of partners, and partnerships norms work best for inter-organizational innovation (cf., Rindfleisch and Moorman 2001; Sivadas and Dwyer 2000)?

- How can a firm simultaneously protect and build on its critical intellectual assets in collaborative relationships?

- What signals does the make-up of these partnerships/alliances send to the market/stakeholders, and what are their effects?

A market-driving environment necessitates a level of planning that is more multi-dimensional, resource intensive, risky, and long-range than one would typically associate with marketing managers in the hightech arena. However, Drucker recognized the value of such long-term planning, and his words are still relevant today in the high-tech markets:

"Long range planning should prevent managers from uncritically extending present trends into the future, from assuming that today's products, services, markets, and technologies will be the products, services, markets, and technologies of tomorrow, and above all, from dedicating their resources and energies to the defense of yesterday" (Drucker 1973, Management: Tasks, Responsibilities, Practices, pp. 122-123).

\section{Customer Co-Creation}

Drucker's writings long emphasized a strong focus on the customer, meeting existing as well as latent needs of the market, and the concomitant need for informationbased strategy development. To this end, firms are increasingly involving customers in the value-creation process through customer co-creation or co-production. Firms that engage in customer co-creation have been shown to experience higher levels of new product success (Well 2005). Although this idea is not new per se, the degree to which companies are harnessing the collective power of communities of consumers through technological developments (e.g., Internet), and customers' desires to play an active role in such development (O'Hern and Rindfleish 2006), has intensified this phenomenon in recent years.

Certainly, users as innovators and involving customers in the creation of the firm's break-through product/service innovations are consistent with Drucker's writings. A key challenge for scholars of 
This is an author-produced, peer-reviewed version of this article. The final, definitive version of this document can be found online at Journal of the Academy of Marketing Science (doi: 10.1007/s11747-008-0101-5) published by Springer. Copyright restrictions may apply.

marketing and innovation is to identify and articulate the organizational conditions that facilitate the effective use of a co-creation model with customers. For example:

- Can traditional organizations structured around the dominant paradigm that "innovation starts in $\mathrm{R} \& \mathrm{D}$ labs, where backroom boys and boffins come up with bright ideas that they pass down a pipeline to waiting consumers" (Leadbeater and Miller 2004, p. 64), truly harness the power of customer co-creation? If so, what organizational conditions are necessary to successfully realize the power of such an approach?

- To what extent is the idea of customer cocreation consistent with the idea of a marketdriving organization? Are the organizational facilitators similar or different?

- Can high-tech companies benefit from customer co-creation more than other types of companies? If break-through innovations are harder to develop, then potentially a cocreation model has more to offer a technologybased business. If so, ho can they use it more successfully?

To be sure, some high-tech customers, such as engineers or computer gamers, have the requisite level of expertise needed to be effective co-creators. However, not all of a high-tech company's customers are sophisticated, possibly posing limits to the co-creation model for high-tech companies. Therefore, a possible moderator between the use of customer co-creation and effective innovation might be the level of customer expertise. These are merely a few of the questions that scholars could answer to truly unleash the power of Drucker's ideas regarding creating value, a customerorientation, and innovation.

\section{Corporate Social Responsibility and Innovation}

Drucker firmly believed that businesses had a responsibility to serve society's larger needs. Throughout his career, he wrote extensively and passionately on the role of business in benefiting society:

"Economic purpose does not mean that the corporation should be free from social obligations. On the contrary, it should be so organized as to fulfill, automatically, its social obligations in the very act of seeking its own self-interest. An individual society based on the corporation can function only if the corporation contributes to social stability and to the achievement of social aims independent of the goodwill or the social consciousness of individual corporate managements" (Drucker 1946, The Concept of the Corporation, p. 17).

"Because of its systematic approach to improving 'man's' livelihood through the systematic organization of economic resources.... management is a basic and dominant institution. Economic change can be made into the most powerful engine for human betterment and social justice" (Drucker 1954, The Practice of Management, p. 4).

This theme of corporate social responsibility (CSR) has recently emerged as a critical topic in the academic literature and business practice. Well-regarded management (e.g., Porter and Kramer 2002; Prahalad 2004) and marketing (e.g., Andreasen 1994; Brown, and Dacin 1997; Drumwright 1994) scholars have highlighted this topic in their work. Consistent with Drucker's views, these scholars emphasize that economic and societal goals need not be at odds, and that a business can make decisions in the service of both simultaneously.

Given that technological innovations are critical to solving seemingly-intractable social problems (Hart and Christensen 2002; Mohr, Sengupta, and Slater 2005), high-tech marketing scholars have a vital role to play in this emerging research area. For example, companies are developing innovative business models that bring needed products and services to base-of-the-pyramid markets (London and Hart 2004), and they are developing new technologies to solve entrenched problems (Hart and Christensen 2002). Hightechnology marketing researchers could build on Drucker's insights about the linking of economic success to social justice by addressing some of the following questions.

- To what extent do high-tech companies engage in CSR (relative to other types of companies)? If the marketing prowess of technology-based companies' is not as sophisticated as other types of companies (cf. Mohr, Slater, and Sengupta 2006), then do they engage in CSR to the same extent?

- When companies link their CSR efforts to the development of break-through innovation (i.e., to solve previously-intractable societal problems), does it help it avoid the myopia of organizational inertia and the innovator's dilemma?

- Do companies in the high-tech arena have a greater opportunity for differentiation from CSR, and are their CSR efforts longer-lived than companies in more traditional 
This is an author-produced, peer-reviewed version of this article. The final, definitive version of this document can be found online at Journal of the Academy of Marketing Science (doi: 10.1007/s11747-008-0101-5) published by Springer. Copyright restrictions may apply.

environments? For example, given that technology has the potential to solve social problems in novel ways (say, by bringing affordable solar energy to impoverished areas of the world), can a high-tech company's CSR efforts garner it enhanced benefits?

- What is the worth of a company's CSR efforts in terms of the financial value to the firm? Do high-tech companies experience a disproportionate financial benefit from its CSR efforts, particularly when its CSR is the development of a break-through innovation in the service of society's needs?

\section{Conclusion}

“... it is frustratingly difficult to cite a significant modern management concept that was not first articulated, if not invented, by Drucker" (Byrne 2005, p. 99).

Acknowledging this widely-held perception, the objective of this essay was to highlight Drucker's contributions to the marketing literature pertaining to high-technology marketing in two key respects: market orientation and innovation. Through a selective survey of his writings, we were able to show that Drucker provided the conceptual underpinnings of many key issues in these areas, years or even decades before they emerged in the academic literature.

Always abreast of cutting-edge issues and always eloquent in his writings, Drucker foreshadowed and offered keen insight into many important issues. Even in his later years, his contributions moved in parallel with much of the academic literature, providing a base for relevance and timeliness. However, more work remains to be done. To this end, we provided illustrative examples of three emerging themes in hightech markets: market driving, customer co-creation, and corporate social responsibility. Contemporary managers and scholars working on marketing of high-tech products and innovations will find Drucker's insights still valuable; and if they are willing to take the time to reflect, understand, and incorporate these insights, Drucker's wisdom will continue to guide research and practice for decades to come.

In closing, to highlight the lasting value of Drucker's insights, we offer the following quote:

"A business .... is defined by the want the customer satisfies when she buys a product or a service. To satisfy the customer is the mission and purpose of every business. The question: 'what is our business?' can, therefore, be answered only by looking at the business from the outside, from the point of view of the customer and the market. What the customer sees, thinks, believes, and wants, at any given time, must be accepted by management as an objective fact and must be taken as seriously as the reports of the salesperson, the tests of the engineer, or the figures of the accountant. And management must make a conscious effort to get answers from the customer herself rather than attempt to read her mind" (Drucker 1973, Management: Tasks, Responsibilities, Practices, pp. 77-79).

\section{References}

Andreasen, Alan R. 1994. "Social Marketing: Its Definition and Domain." Journal of Public Policy \& Marketing 13 (Spring): 108-115.

Atuahene-Gima, Kwaku. 2005. "Resolving the Capability-Rigidity Paradox in New Product Innovation." Journal of Marketing 69 (4): 61-83.

, Stanley F. Slater, and Eric M. Olson. 2005. "The Contingent Value of Responsive and Proactive Market Orientations for New Product Program Performance." Journal of Product Innovation Management 22 (6): 464-482.

Arthur, Brian W. 1996. "Increasing Returns and the New World of Business." Harvard Business Review 74 (July-August): 100-109.

Baker, William E. and James M. Sinkula. 2005. "Market Orientation and the New Product Paradox." Journal of Product Innovation Management 22 (6): 483-502.

Byrne, John. 2005. "The Man Who Invented Management: Why Peter Drucker's Ideas Still Matter." Business Week November 28: 97-106.

Brown, Tom J. and Peter A. Dacin. 1997. "The Company and The Product: Corporate Associations and Consumer Product Responses." Journal of Marketing, 61 (January): 68-85.

Chandy, Rajesh and Gerard Tellis. 1998. "Organizing for Radical Product Innovation: The Overlooked Role of Willingness to Cannibalize." Journal of Marketing Research, 35 (4): 474-487.

and 2000. "The Incumbent's Curse? Incumbency, Size, and Radical Product Innovation." Journal of Marketing 64 (3): 1-17. 
This is an author-produced, peer-reviewed version of this article. The final, definitive version of this document can be found online at Journal of the Academy of Marketing Science (doi: 10.1007/s11747-008-0101-5) published by Springer. Copyright restrictions may apply.

Christensen, Clayton. 1997. The Innovator's Dilemma. Boston: Harvard Business School Press. and Raynor. 2003. The Innovator's Solution. Boston: Harvard Business School Press.

Daneels, Erwin. 2002. "The Dynamics of Product Innovation and Firm Competencies." Strategic Management Journal 23 (12): 1095-1121.

Day, George. 1994. "The Capabilities of Market-Driven Organizations." Journal of Marketing 58 (4): 3752.

Day, George and Robin Wensley. 1988. "Assessing Advantage: A Framework for Diagnosing Competitive Superiority." Journal of Marketing 52 (April): 1-20.

Deshpande, Rohit, John U. Farley, and Frederick E. Webster Jr. 1993. "Corporate Culture, Customer Orientation, and Innovativeness in Japanese Firms: A Quadrad Analysis." Journal of Marketing 57 (January): 23-37.

Dhebar, Anirudh. 1996. "Speeding High-Tech Producer, Meet the Balking Consumer." Sloan Management Review 37 (2): 37-49.

Drucker, Peter. 1946. Concept of the Corporation. New York: John Day Company.

. 1954. The Practice Of Management. New York: Harper \& Row Publishers.

. 1964. Managing for Results. New York: Harper \& Row.

1973. Management: Tasks, Responsibilities, Practices. New York: Harper \& Row Publishers.

. 1985a. Innovation and Entrepreneurship. New York: Harper \& Row Publishers.

. 1985b. "The Discipline of Innovation." Harvard Business Review 63 (May-June): 67-73.

. 1992. Managing for the Future. Truman Talley/E.P. Dutton.

. 1993. The Ecological Vision. Transaction Publishers.

1999. Management Challenges for the $21^{\text {st }}$ Century. HarperCollins.
Drumwright, Minette E. 1994. "Socially Responsible Organizational Buying: Environmental Concern as a Noneconomic Buying Criterion." Journal of Marketing 58 (July): 1-20.

Dutta, Shantanu, Om Narasimhan, and Surendra Rajiv. 1999. "Success in High-Technology Markets: Is Marketing Capability Critical?" Marketing Science 18 (4): 547-568.

Ellis, Paul D. 2006. "Market Orientation and Performance: A Meta-Analysis and Cross-National Comparison." Journal of Management Studies 43 (5): 1089-1107.

Fisher, Robert, Elliot Maltz, and Bernard Jaworski. 1997. "Enhancing Communication Between Marketing and Engineering: The Moderating Role of Relative Functional Identification." Journal of Marketing 61 (July): 54-71.

Goldenberg, Jacob, Barak Libai, and Eitan Muller. 2002. "Riding the Saddle: How Cross-Marketing Communications Can Create a Major Slump in Sales.” Journal of Marketing, 66 (April): 1-16.

Goolsby, Jerry R. 1992. "A Theory of Role Stress in Boundary Spanning Positions of Marketing Organizations." Journal of the Academy of Marketing Science 20 (Spring): 155-164.

Gupta, Ashok K., S. P. Raj, and David Wilemon. 1986. "A Model for Studying R\&D-Marketing Interface in the Product Innovation Process." Journal of Marketing 50 (2): 7-17.

Han, Jin K., Namwoon Kim, and Rajendra K. Srivastava. 1998. "Market Orientation and Organizational Performance: Is Innovation a Missing Link?" Journal of Marketing 62 (October): $30-45$.

Hart, Stuart and Clayton M. Christensen. 2002. "The Great Leap: Driving Innovation From the Base of the Pyramid." MIT Sloan Management Review 44 (Fall): 51-57.

Hauser, John, Gerard J. Tellis, Abbie Griffin. 2006. "Research on Innovation: A Review and Agenda for Marketing Science." Marketing Science 25 (Nov/Dec): 687-720.

Henderson, Rebecca. 2006. "The Innovator's Dilemma as a Problem of Organizational Competence." Journal of Product Innovation Management 23 (January): 5-11. 
This is an author-produced, peer-reviewed version of this article. The final, definitive version of this document can be found online at Journal of the Academy of Marketing Science (doi: 10.1007/s11747-008-0101-5) published by Springer. Copyright restrictions may apply.

Hill, Charles W. J. 1997. "Establishing a Standard: Competitive Strategy and Technological Standards in Winner-Take-All Industries." The Academy of Management Executive 11 (May): 7-25.

Hills, Stacey Barlow and Shikhar Sarin. 2003. "From Market Driven to Market Driving: An Alternate Paradigm for Marketing in High-Technology Industries." Journal of Marketing Theory and Practice 11 (Summer): 13-24.

Homburg, Christian and Christian Pflesser. 2000. "A Multiple-Layer Model of Market-Oriented Organizational Culture: Measurement Issues and Performance Outcomes." Journal of Marketing Research 37 (4): 449-462.

Hult, Tomas M. G., David Ketchen Jr., and Stanley F. Slater. 2005. "Market Orientation and Performance: An Integration of Disparate Approaches." Strategic Management Journal 26 (12): 1173-1181.

Im, Subin, and John P. Workman Jr. 2004. "Market Orientation, Creativity, and New Product Performance in High-Technology Firms." Journal of Marketing 68 (2): 114-132.

Jaworski, Bernard J. and Ajay K. Kohli. 1993. "Market Orientation: Antecedents and Consequences." Journal of Marketing 57 (July): 53-70.

, and Arvind Sahay. 2000. "Market-Driven Versus Driving Markets." Journal of the Academy of Marketing Science 28 (1): 45 - 54.

John, George, Allen Weiss, and Shantanu Dutta. 1999. "Marketing in Technology-Intensive Markets: Toward A Conceptual Framework." Journal of Marketing (63) Special Issue: 78-91.

Kohli, Ajay K., and Bernard J. Jaworski. 1990. "Market Orientation: The Construct, Research Propositions, and Managerial Implications." Journal of Marketing 54 (April): 1-18.

Kyriakopoulos, Kyriakos and Christine Moorman. 2004. "Tradeoffs in Marketing Exploitation and Exploration Strategies: The Overlooked Role of Market Orientation." International Journal of Research in Marketing 21 (3): 219-240.

Leadbeater, Charles and Paul Miller. 2004. The Pro-Am Revolution. London: Demos.

Leonard-Barton, Dorothy. 1992. "Core Capabilities and Core Rigidities: A Paradox in Managing New
Product Development." Strategic Management Journal 13 (2): 111-126.

Leonard-Barton, Dorothy, Edith Wilson, and John Doyle. 1995. "Commercializing Technology: Understanding User Needs." In Business Marketing Strategy. Eds. V.K. Rangan, et al. Chicago: Irwin, 281-305.

Leonard-Barton, Dorothy and Jeffry Rayport. 1997. "Spark Innovation Through Empathic Design." Harvard Business Review November-December: 102-113.

London, Ted and Stuart Hart. 2004. "Reinventing Strategies for Emerging Markets: Beyond the Transnational Model." Journal of International Business Studies 35 (Sept): 350-371.

Lukas, Bryan A. and O. C. Ferrell. 2000. "The Effect of Market Orientation on Product Innovation." Journal of the Academy of Marketing Science 28 (2): 239-247.

Maltz, Elliot, William E. Souder, and Ajith Kumar. 2001. "Influencing R\&D/Marketing Integration and the Use of Marketing Information by R\&D Managers: Intended and Unintended Effects of Managerial Actions." Journal of Business Research 53 (1): 69-82.

Mohr, Jakki, Sanjit Sengupta, and Stanley Slater. 2005. Marketing of High-Technology Products and Innovations. Upper Saddle River: Prentice Hall Business Publishing.

Moore, Geoffrey. 1991. Crossing the Chasm. New York: HarperBusiness.

Narver, John. C. and Stanley F. Slater. 1990. “The Effect of Market Orientation on Business Profitability." Journal of Marketing 54 (October): 20-35.

Narver, John C., Stanley F. Slater, and Douglas L. MacLachlan. 2004. "Responsive and Proactive Market Orientations and New Product Success." Journal of Product Innovation Management 21 (5): 334-347.

O'Hern, Matthew and Aric Rindfleisch. 2006. "The Emerging Logic of Customer co-Creation." University of Wisconsin-Madison: Working Paper.

Prahalad, C.K. 2004. The Fortune at the Bottom of the Pyramid. Wharton School Publishing. 
This is an author-produced, peer-reviewed version of this article. The final, definitive version of this document can be found online at Journal of the Academy of Marketing Science (doi: 10.1007/s11747-008-0101-5) published by Springer. Copyright restrictions may apply.

Porter, Michael and Mark Kramer. 2002. “The Competitive Advantage of Corporate Philanthropy." Harvard Business Review December: 5-16.

Reid, Susan E., and Ulrike de Brentani. 2004. "The Fuzzy Front End of New Product Development for Discontinuous Innovations: A Theoretical Model." Journal of Product Innovation Management 21 (May): 170-185.

Rindfleisch, Aric and Christine Moorman. 2001. "The Acquisition and Utilization of Information in New Product Alliances: A Strength-of-Ties Perspective." Journal of Marketing, 65 (April): 1-19.

Rinehart, Lloyd M., M. Bixby Cooper, George D. Wagenheim. 1989. "Furthering the Integration of Marketing and Logistics Through Customer Service in the Channel." Journal of the Academy of Marketing Science 17 (1): 63-71.

Ruekert, Robert W. and Orville Walker. 1987. "Marketing's Interaction with Other Functional Units: A Conceptual Framework and Empirical Evidence." Journal of Marketing, 51 (1): 1-19.

Sarin, Shikhar and Vijay Mahajan. 2001. "The Effect of Reward Structures on the Performance of CrossFunctional Product Development Teams." Journal of Marketing 65 (April): 35-53.

Sethi, Rajesh, Daniel C. Smith, and C. Whan Park. 2001. "Cross-Functional Product Development Teams, Creativity, and the Innovativeness of New Consumer Products." Journal of Marketing Research 38 (February): 73-85.

Schilling, Melissa A. 2002. "Technology Success and Failure in Winner-Take-All Markets: The Impact of Learning Orientation, Timing, and Network Externalities." Academy of Management Journal 45 (April): 387-397.

Schumpeter, Joseph. 1942. Capitalism, Socialism, and Democracy. New York: Harper \& Row.

Sivadas, Eugene and F. Robert Dwyer. 2000. "An Examination of Organizational Factors Influencing New Product Success in Internal and AllianceBased Processes." Journal of Marketing 64 (January): 31-49.
Slater, Stanley, Tomas Hult, and Eric Olson. 2007. “On The Importance of Matching Strategic Behavior and Target Market Selection of Business Strategy in High-Tech Markets." Journal of the Academy of Marketing Science 35 (Spring): 5-17.

and John C. Narver. 1994. "Does Competitive Environment Moderate the Market Orientation Performance Relationship?" Journal of Marketing 58 (1): 46-55.

Srinivasan, Raji, Arvind Rangaswamy and Gary L. Lilien. 2004. "First In, First Out? The Effects of Network Externalities on Pioneer Survival." Journal of Marketing, 68 (January): 41-58.

Srivastava, Rajendra K, Tasadduq A. Shervani, and Liam Fahey. 1998. "Market-Based Assets and Shareholder Value: A Framework for Analysis." Journal of Marketing 62 (January).

Tellis, Gerard J. 2006. "Disruptive Technology or Visionary Leadership?" Journal of Product Innovation Management 23 (1): 34-38.

Tellis, Gerard J., Peter N. Golder, and Clayton Christensen. 2001. Will and Vision: How Latecomers Grow to Dominate Markets. New York: McGraw Hill.

Thompson, Debora V., Rebecca W. Hamilton, and Roland T. Rust. 2005. "Feature Fatigue: When Product Capabilities Become Too Much of a Good Thing." Journal of Marketing Research 42 (November): 431-442.

Vardarajan, Rajan, Manjit S. Yadav, and Venkatesh Shanker. 2005. "First Mover Advantage on the Internet: Real or Virtual." Marketing Science Institute Working Paper \# 05-100. Cambridge, MA: Marketing Science Institute.

Vargo, Stephen L. and Robert F. Lusch 2004. "Evolving to a New Dominant Logic for Marketing." Journal of Marketing 68 (January): 1-17.

von Hippel, Eric, Stefan Thomke, and Mary Sonnack. 1999. "Creating Breakthroughs at 3M." Harvard Business Review September-October: 47-57.

Well, Melanie. 2005. "Have it Your Way.” Forbes.com. February 14. 